\title{
Application of Network Program Technique in Software Development and Management
}

\author{
Yanlin Tao , Limei Cui \\ Computer Science and Engineering School, Qujing Normal University 655011
}

Keywords: project management, Network Program Technique, rate of progress

\begin{abstract}
This paper analyses the Network Program Technique from the perspective of its principle and procedures of implementation as well as its merits and demerits, with the aim to solve the problem of overtime and overspend in software development, and provide the incumbent software developer with reference and help.
\end{abstract}

\section{Introduction}

As a part of Operations Research, Network Program Technique originated from a kind of management technique of scientific program in the mid-50s of the 20th century. Its basic principle is as follows: dividing the required work into several small projects (assignments), rearranging according to assignments' successive sequence, then applying network diagram to overall planning and deploying the work or the whole project, all these are envisioned to serve the purpose of completing the whole project with the least amount of resources and the highest rate ${ }^{[1]}$. Statistical data indicates that the project can be finished ahead of time by $15 \%-20 \%$ with the cost minimized by $10 \%-15 \%$ under the condition of adopting PERT ${ }^{[2]}$.

\section{Project Background}

Fuyuan is a county of good ecology, which has always enjoyed the reputation of "Hometown of Eight Treasures" and is known for adequate natural resources. Within the region not only fills with cultivatable land, hydro energy, plant and animal resources, but also abounds in abundant mineral resources ${ }^{[3]}$. Teng Yuan Economy \&Trading Co., Ltd is located in Fuyuan county and deals in mineral products and metal materials. It contains seven affiliated agencies. In order to monitor each branch's sales volume and turnover, meanwhile to sense market demand, track prices, inventory and competitors' conditions, the company decides to set up a tracking system by authorizing De Xiang Software Technology Co., Ltd to develop it. This company uses Network Program Technique to control the development progress of information system, ensuring that the project is to be completed on schedule.

\section{Estimate of Project Duration}

Below is the condition that Teng Yuan Economy \&Trading Co., Ltd offers: to complete the system development project within 75 weeks with an 11 million-Yuan total investment. Building a project schedule shouldn't pay excessive attention to minor details so that to flexibly adjust it in the future on account of the unnecessary macro-control of the rate of progress, as for the extent the work is to be decomposed can only be relied on the project leader's experience ${ }^{[4]}$. The project team will divide the whole project into 22 specific tasks in line accordance with general experience and experts' suggestions: 
A Data Collecting; B Research Feasibility ; C Problem Specification;

D Meeting Clients; E Current System Research F Need Defining;

G Systematic Analysis report; H Data Input, Output; I Date Processing and Database Set-up;

J Analysis and Assessment; K System Design; L Software Development;

M Hardware development; N Network development; O Development Report Prepare;

P Software Testing; Q Hardware Testing; R Network Testing;

S Testing Report Preparing; T Training; U Installation; V Implementation report Preparing;

\section{Network Diagram Drawing}

We are able to draw a preliminary network program diagram on the basis of the tasks subdivided above, as figure 1 shows. Codes above the arrows indicate task codes, while numbers below the estimated project duration.
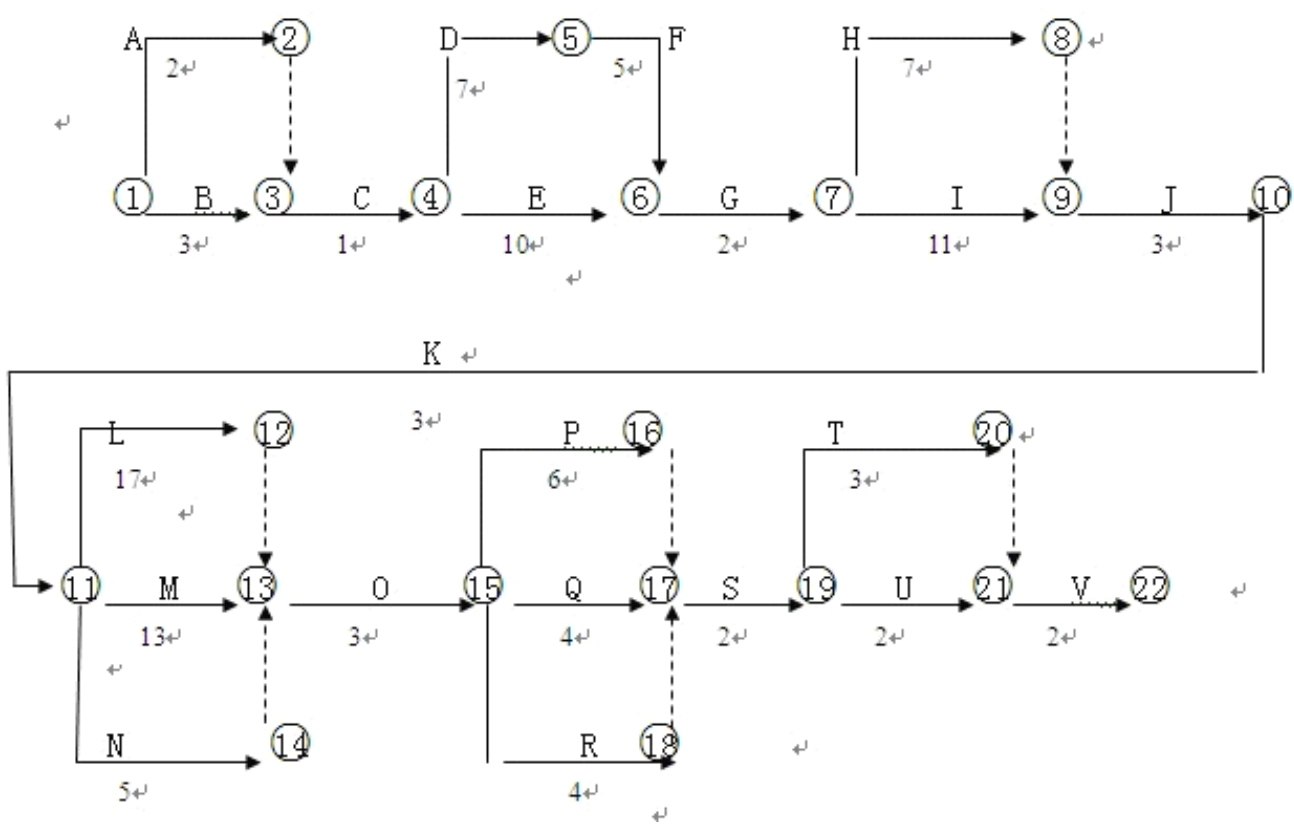

Fig.1 Teng Yuan Economy \&Trading Co., Ltd's Network diagram of development project for production and sales

\section{Network Time Calculation}

Time parameters of the network diagram can be calculated based on the diagram above. The project team primarily sets 60 weeks for the project by following the company's time order. In addition, the project team will normally calculate the required network time by sticking to each process' estimated working time as well as following the previous experience. Two situations' results can be worked out below according to the computing method of time parameters and critical path, as figure 1 shows:

Table 1 Project Schedule Sheet

\begin{tabular}{|c|c|c|c|c|c|c|c|}
\hline \multirow[t]{2}{*}{ No. } & \multirow[t]{2}{*}{ work } & \multirow[b]{2}{*}{$\begin{array}{l}\text { Estimat } \\
\text { ed } \\
\text { project } \\
\text { duration } \\
\text { /week }\end{array}$} & \multicolumn{2}{|c|}{ The earliest } & \multicolumn{2}{|c|}{ The latest } & \multirow{2}{*}{$\begin{array}{l}\text { Total } \\
\text { slack/w } \\
\text { eek }\end{array}$} \\
\hline & & & $\begin{array}{l}\text { Start } \\
\text { time }\end{array}$ & $\begin{array}{l}\text { End } \\
\text { time }\end{array}$ & $\begin{array}{l}\text { Start } \\
\text { time }\end{array}$ & End time & \\
\hline
\end{tabular}




\begin{tabular}{|c|c|c|c|c|c|c|c|}
\hline A & Date Collecting & 2 & 0 & 2 & -7 & -5 & -7 \\
\hline $\mathrm{B}$ & Research Feasibility & 3 & 0 & 3 & -8 & -5 & -8 \\
\hline $\mathrm{C}$ & $\begin{array}{l}\text { Problem } \\
\text { Specification }\end{array}$ & 1 & 3 & 4 & -5 & -4 & -8 \\
\hline $\mathrm{D}$ & Meeting Clients & 7 & 4 & 11 & -4 & 3 & -8 \\
\hline $\mathrm{E}$ & $\begin{array}{l}\text { Current System } \\
\text { Research }\end{array}$ & 10 & 4 & 14 & -2 & 8 & -6 \\
\hline $\mathrm{F}$ & Need Defining & 5 & 11 & 16 & 3 & 8 & -8 \\
\hline G & $\begin{array}{l}\text { Systematic Analysis } \\
\text { Report }\end{array}$ & 2 & 16 & 17 & 8 & 10 & -8 \\
\hline $\mathrm{H}$ & Data Input, Output & 7 & 18 & 25 & 14 & 21 & -4 \\
\hline $\mathrm{I}$ & $\begin{array}{l}\text { Date Processing and } \\
\text { Database Set-up }\end{array}$ & 11 & 18 & 29 & 10 & 21 & -8 \\
\hline $\mathrm{J}$ & $\begin{array}{l}\text { Analysis and } \\
\text { Assessment }\end{array}$ & 3 & 29 & 32 & 21 & 19 & -8 \\
\hline K & System Design & 3 & 32 & 35 & 24 & 27 & -8 \\
\hline $\mathrm{L}$ & $\begin{array}{l}\text { Software } \\
\text { Development }\end{array}$ & 17 & 35 & 52 & 27 & 44 & -8 \\
\hline $\mathrm{M}$ & $\begin{array}{l}\text { Hardware } \\
\text { Development }\end{array}$ & 13 & 35 & 48 & 31 & 44 & -4 \\
\hline $\mathrm{N}$ & $\begin{array}{l}\text { Network } \\
\text { Development }\end{array}$ & 5 & 35 & 40 & 39 & 44 & 4 \\
\hline $\mathrm{O}$ & $\begin{array}{l}\text { Development } \\
\text { Report Preparing }\end{array}$ & 3 & 52 & 55 & 44 & 47 & -8 \\
\hline $\mathrm{P}$ & Software Testing & 6 & 55 & 61 & 47 & 53 & -8 \\
\hline Q & Hardware Testing & 4 & 55 & 59 & 49 & 53 & -6 \\
\hline $\mathrm{R}$ & Network Testing & 4 & 55 & 59 & 49 & 53 & -6 \\
\hline$S$ & $\begin{array}{l}\text { Preparing Testing } \\
\text { report }\end{array}$ & 2 & 61 & 63 & 53 & 55 & -8 \\
\hline $\mathrm{T}$ & Training & 3 & 63 & 66 & 55 & 58 & -8 \\
\hline $\mathrm{U}$ & Installation & 2 & 63 & 66 & 56 & 58 & -7 \\
\hline $\mathrm{V}$ & $\begin{array}{l}\text { Implementation } \\
\text { Report Preparing }\end{array}$ & 2 & 66 & 68 & 58 & 60 & -8 \\
\hline
\end{tabular}

From the information of figure 1, the whole project is to be completed in 68 weeks, which is 7 weeks shorter than the required 75 weeks the company initially demands but is 8 weeks longer than De Xiang Science \& Technology Co., Ltd's 60 weeks.

\section{Critical Path Confirmation}

In figure 1, the channel from starting point (1) to ending point (22) is called route(path), and the working time in each route is different. Here are a few representative ones below:

$$
\begin{aligned}
& \text { (1)-(2)-(3)-(4)-(6)-(7)-(9)-(10)-(11)-(13)-(15)-(17)-(19)-(21)-(22) } 58 \text { weeks in total } \\
& \text { (1)-(3)-(4)-(5)-(6)-(7)-(9)-(10)-(11)-(13)-(15)-(17)-(19)-(21)-(22) } 61 \text { weeks in total }
\end{aligned}
$$


(1) - (3) - (4) - (5) - (6) - (7) - (9) - (10) - (11) - (12) - (13) - (15) - (16) - (17) - (19) - (20) - (21) - (22) 68 weeks in total

From all the routes above, the last route takes the longest time to finish the project, which shows the project duration of developing the whole system will be 68 weeks. Any task in this route delays, the project duration will be postponed and vice versa. Therefore, it naturally comes to setting the longest route of the network diagram as a critical path ${ }^{[5]}$.

\section{Project Implementation and Rate of Progress Control}

It's not hard to find the expected duration of task I "Date processing and database set-up" can be reduced to 8 weeks from 11 weeks and E "Researching current system" 8 weeks from 11 weeks after analyzing the corresponding network diagram. So the progress plan in the phase of project implementation needs to be amended. In this case, it focuses on compressing time in each key progress, continuously reducing time difference in key progresses and modifying the network program's initial plan by taking full advantage of time difference, then enabling it the most rational use of the most ideal project duration, the lowest cost and resources.

\section{Project Summarization}

De Xiang Science \& Technology Co., Ltd succeeds in adopting the thought of Network Program Technique, following modern project management mode and achieving the goal of the project on the course of project implementation. The product perfectly meets customer demand with good quality, timely schedule and reasonable cost. Also, the project team finally comes up with the time of 69 weeks for the project after systematically analyzing it by adopting Network Program Technique, which is 6 weeks shorter than the original plan and meanwhile saves 6 weeks' valuable time for the company.

\section{References}

[1] anonymity.Project and Project Management[EB/OL]. http://bbs.jzcad.com/thread-35774-1-1.html. 2007-8-31

[2] “Operations Research”Teaching Materials Writing Group. Operations Research [M].Beijing: Tsinghua University Press,2005.page286

[3] anonymity.Fuyuan county[EB/OL] http://baike.baidu.com/view/766528.htm

[4] Zhao Tao,Qi Ershi,Management[M].Tianjing: Tianjing University Press,2004

[5] Hu Yunquan,Operations Research Tutorial[M].Beijing: Tsinghua University Press,2006

[6] Yao Chao, Operations Research [M].Beijing:Science Press, 2003

[7] Xun Guanghui,Operations Research Manual[M].Bejing:Science Press, 2001

[8] A Few Thoughts and Suggestions about the Application of Network Program Technique [J]Anhui architecture.2000

[9] Anonymity. Plant Maintenance Engineering [EB/OL]

http://www.pme.com.cn/message/2003/message3/030308.htm 